10.5216/ia.v35i1.11024

\title{
INDÚSTRIA CULTURAL, COMPUTADOR E TELEVISÃO \\ CONSEQUÊNCIAS PARA A CONSCIÊNCIA \\ E O COMPORTAMENTO HUMANOS NA SOCIEDADE \\ CONTEMPORÂNEA*
}

Luís CÉsAR SOuZA, da Universidade Federal de Goiás, Campus Jataí

\begin{abstract}
RESUMO: Este artigo subdivide-se em três partes: na primeira, discutirse-ão aspectos mais abrangentes acerca da relação entre a indústria cultural e algumas implicações sobre a consciência e o comportamento humanos. Na segunda parte, trataremos de uma das principais tecnologias que a cada dia tem sido utilizada por um número maior de pessoas: o computador. Na última parte, discutiremos a dimensão ideológica da televisão e a falsa consciência que decorre das ilusões incutidas por ela. Analisaremos as implicações dessas tecnologias na modificação do pensamento e do comportamento das gerações atuais. As análises serão norteadas, principalmente, pelas considerações de Max Horkheimer e Theodor W. Adorno a respeito da indústria cultural e da televisão bem como das análises de Denis de Rougemont sobre as vantagens anunciadas pelas novas tecnologias.
\end{abstract}

PALAVRAS-CHAVE: Indústria cultural. Tecnologia. Comportamento humano. Sociedade contemporânea.

\section{INDÚSTRIA CULTURAL, CONSCIÊNCIA E COMPORTAMENTO HUMANOS}

Ao fazermos um balanço da sociedade contemporânea, sobretudo no tocante ao nível de esclarecimento acerca das contradições imanentes à sociedade capitalista, possivelmente nos surpreenderemos quando a comparamos a períodos anteriores, como o século XVIII, com o lluminismo e os acontecimentos da Revolução Francesa. Sob as condições de existência

* Artigo recebido em 13/05/2009 e aprovado em 25/09/2009. 
na sociedade capitalista contemporânea, que se caracteriza por acentuado desenvolvimento das forças produtivas e pelo acirramento da exploração nas relações de produção, não tem causado espanto o fato de assistirmos permanentemente à ausência da predominância de idéias e espíritos esclarecidos como também ao recuo de movimentos e ações revolucionárias que pretendam subverter a ordem capitalista vigente. Pois, no século XVIII, as idéias e ideologias poderiam explicitamente ser vinculadas a uma pessoa, autoridade ou a um membro de uma classe social em declínio - como a aristocracia e a realeza - ao de uma classe social em ascensão - como a burguesia - ou, ainda, a um membro de uma classe social que, explorada tanto na sociedade feudal em declínio como na ascendente sociedade capitalista, de ideologia liberal, mantém-se, conforme indicou Marx (2004) por volta das revoluções do final da década de 1840, como aquela que carrega em si a potencialidade revolucionária: a classe trabalhadora. Na sociedade contemporânea - muitos se apressam em afirmar - as distinções de classe já não existem; vivemos uma era de diluição das fronteiras modernas, que demarcavam com clareza, não somente mas sobretudo, os interesses antagônicos entre distintas classes sociais ${ }^{1}$. Pois, conforme os defensores dessa ideologia, se a grande maioria da classe trabalhadora não se reconhece mais como classe explorada; se a empregada doméstica vai às mesmas boutiques às quais vai sua patroa; se a alienação no segregado processo de produção capitalista, no qual o produto produzido pelo trabalhador lhe aparece totalmente estranho, permite hoje ao alienado adquirir o carro "zero quilômetro" e viajar com frequência à beach; se o negro anda no mesmo carro que o empresário branco; se as pessoas não reagem diante das incômodas atrocidades geradas pelo sistema, como a fome e as guerras. por exemplo, tudo isso, e muito mais, tem levado alguns a aceitar e admitir a idéia de que vivemos numa sociedade na qual os interesses de classe não são mais antagônicos, mas, antes, convergentes e conciliatórios. Uma sociedade na qual teríamos chegado ao fim da história pelo suposto triunfo do capitalismo e da ideologia liberal, em detrimento de outras possibilidades de existência humana ${ }^{2}$. Embora de caráter absolutamente ideológico e falacioso, tal interpretação é permanentemente reforçada por um fenômeno moderno de eficiência incomparável: a denominada Indústria Cultural ${ }^{3}$.

Horkheimer e Adorno (1985), ao analisarem esse fenômeno, colocamnos o desafio de compreender o mecanismo pelo qual a indústria capitalista não deixa qualquer atividade humana escapar de seus tentáculos. No caso em questão, a cultura da sociedade moderna sofre uma metamorfose na medida em que é submetida aos interesses econômicos e ideológicos da classe dominante. De produções artísticas e culturais, a que subtendem 
objetivação e subjetivação por parte do sujeito criador como também por parte do sujeito receptor, a era dos produtos da indústria cultural, produzidos em série, implica a um só tempo a massificação e a banalização da cultura.

Em se tratando de indústria cultural, a principal via de exploração de seus produtos calca-se na "diversão". E diversão na sociedade capitalista é sinônimo de esquecimento do pesado e insuportável fardo do trabalho, de alívio e compensação da força dispensada ao processo de produção, ou seja, descansar para posteriormente retornar à exploração do trabalho produtivo, que faz girar para a frente a roda do sistema. Para ter êxito no que tange ao esquecimento do momento de trabalho, a diversão não deve exigir de quem dela usufrui qualquer atividade intelectual, qualquer pensamento ou abstração. Segundo Horkheimer e Adorno,

a diversão é o prolongamento do trabalho sob o capitalismo tardio. Ela é procurada por quem quer escapar ao processo de trabalho mecanizado, para se pôr de novo em condições de enfrentá-lo. [...] Ao processo de trabalho na fábrica e no escritório só se pode escapar adaptando-se a ele durante o ócio. Eis aí a doença incurável de toda diversão. O prazer acaba por se congelar no aborrecimento, porquanto, para continuar a ser um prazer, não deve mais exigir esforço e [...] o espectador não deve ter necessidade de nenhum pensamento próprio. Toda ligação lógica que pressuponha um esforço intelectual é escrupulosamente evitada. (HorkHeimer; Adorno, 1985, p. 128)

À medida que as pessoas atribuem à diversão a expectativa de fuga do trabalho diário, dificulta-se a possibilidade de o trabalhador objetivar-se com seu próprio trabalho, isto é, anula-se a possibilidade de reconhecimento da ação humana como produtora das reais condições de existência social, impedindo-se o reconhecimento da situação de exploração em que vive a classe trabalhadora dentro do sistema capitalista.

Mediado pela diversão, o controle sobre os consumidores não ocorre por decreto, mas pela resistência por parte das pessoas de compreender qualquer coisa que esteja além do entretenimento, processo esse que colabora para a perpetuação tanto da situação de infantilidade social - pois à pessoa não é dada a possibilidade de desenvolvimento da autonomia, mas, ao contrário, a manutenção de seu espírito à condição de menoridade - como da anulação da possibilidade de rebelar-se contra a heteronomia que tem predominado nas relações humanas. Quando há insatisfação, ela ocorre por conta de desvios daquilo que é oferecido pela indústria cultural em relação à expectativa do consumidor ou telespectador ou por conta da incompatibilidade com esses mesmos fatos, e não porque seus produtos venham carregados de alto teor ideológico. De acordo com Horkheimer e Adorno 
(1985, p. 135), “mesmo quando o público se rebela contra a indústria cultural, essa rebelião é o resultado lógico do desamparo para o qual ela própria o educou". Com isso, é evitado o processo de diferenciação entre o sujeito que consome e o objeto da indústria cultural necessário à construção da autonomia. A revolta dos consumidores não é contra a idiotização inculcada por ela, mas, antes, pela ausência de sua adequação àquilo que eles esperavam como receptores, ou seja, um processo de absoluta integração - e não diferenciação - entre sujeito e objeto.

Divertir-se significa estar de acordo. Isso só é possível se isso se isola do processo social em seu todo, se idiotiza e abandona desde o início a pretensão inescapável de toda obra, mesmo da mais insignificante, de refletir em sua limitação o todo. Divertir significa sempre: não ter que pensar nisso, esquecer o sofrimento até mesmo onde ele é mostrado. (HorkHeimer; Adorno, 1985, p. 135)

Não se espantar com as atrocidades que ocorrem diariamente e que são veiculadas pela indústria cultural constitui-se numa marcante e lamentável característica das pessoas que se integraram ao modo de vida da sociedade contemporânea. Essa banalização ocorre em virtude da (con) fusão entre a vida real e o espetáculo apresentado pela indústria cultural, na qual a primeira é virtualizada e o segundo, apresentado como realidade. Os produtos da indústria cultural apresentados pelos meios de comunicação não deixam mais à fantasia e ao pensamento dos espectadores nenhuma dimensão na qual eles possam passear e divagar livres do controle dos dados exatos, o que leva, por sua vez, ao adestramento do espectador, que deve identificar-se imediatamente com a realidade. Esse adestramento resulta da atrofia do pensamento imaginativo e abstrato necessário à diferenciação e à crítica. Segundo Horkheimer e Adorno (1985), a atrofia da imaginação e da espontaneidade do consumidor cultural não necessita mais recorrer a mecanismos e artimanhas psicológicos, pois os próprios produtos da indústria cultural paralisam essas capacidades em virtude de sua constituição objetiva. Eles são fabricados de tal modo que sua apreensão adequada exige presteza, dom de observação, conhecimentos específicos, ao mesmo tempo em que proíbem a atividade intelectual do espectador caso ele não queira perder os fatos que desfilam velozmente diante de seus olhos.

Há quem resista aos tentáculos da indústria cultural por meio de olhar crítico, discernimento, manifestações individuais e coletivas. No entanto, segundo Horkheimer e Adorno (1985, p. 123) "quem resiste só pode sobreviver integrando-se. Uma vez registrado em sua diferença pela indústria cultural, ele (o indivíduo) passa a pertencer a ela assim como o participante da refor- 
ma agrária ao capitalismo". E quem ousa resistir ao processo de integração, continuam, "é punido com uma impotência econômica que se prolonga na impotência espiritual do individualista. Excluído da atividade industrial, ele terá sua insuficiência facilmente comprovada" (p. 125). Isso talvez possa explicar a generalizada sensação de impotência que tem assolado um sem-número de pessoas que, se antes estavam dispostas a encarar o desafio de construir uma organização social diferente da atual, aos poucos, vão sucumbindo aos tentáculos do modo de produção e organização social capitalista.

No tocante à arte, a indústria cultural impôs uma nova maneira de concebê-la e apreciá-la. A reprodutibilidade técnica da obra de arte de qualidade bem como a produção em série de qualquer produção artística têm implicado a banalização da arte e da cultura, outra deplorável consequência da subordinação da cultura aos interesses da indústria capitalista. A primeira justificativa, como inúmeras outras da ideologia liberal, é a de democratização do acesso à arte, pois, se do ponto de vista sócio-econômico um proprietário dos meios de produção pode adquirir uma obra de arte por elevada quantia, que corresponderia ao seu digno valor artístico-cultural, uma pessoa desprovida de recursos financeiros ou encontraria significativos obstáculos ou não poderia fazê-lo. Não o podendo, e uma vez não havendo disposição por parte da classe dominante em proporcionar às massas uma elevação do seu nível sócio-econômico, uma alternativa - inclusive, não se deve esquecer, lucrativa - foi a facilitação da aquisição de cópias de obras artísticas de qualidade pela classe de baixo poder aquisitivo. Porém, e em fato, essa suposta democratização do acesso à arte não eleva culturalmente as massas; antes leva ao que poderíamos denominar de nivelamento cultural por baixo, pois, para apreciar e contemplar uma obra de arte, é necessário cultivar permanentemente a sensibilidade, a autonomia e o olhar crítico por meio de uma rigorosa formação cultural - potencialidades essas negligenciadas ou impedidas pela indústria cultural. Segundo Horkheimer e Adorno, as obras de arte têm sido apresentadas, a preços reduzidos, como slogans políticos e inculcadas a um público relutante.

Elas tornaram-se tão acessíveis quanto os parques públicos. Mas isso não significa que, ao perderem o caráter de uma autêntica mercadoria, estariam preservadas na vida de uma sociedade livre, mas, ao contrário, que agora caiu também a última proteção contra sua degradação em bens culturais. A eliminação do privilégio da cultura pela venda em liquidação dos bens culturais não introduz as massas nas áreas de que eram antes excluídas, mas serve, ao contrário, nas condições sociais existentes, justamente para a decadência da cultura e para o progresso da incoerência bárbara. (HORKHEIMER; ADORNo, 1985, p. 150) 
Com a massificação, as obras de arte têm sido colocadas à venda junto com quaisquer outras mercadorias ou bens culturais. Consequentemente, se para os consumidores tem predominado a máxima de que quanto menos custa uma mercadoria menor o seu valor, a mesma fórmula passa a valer para a cultura. "Transformadas em simples brindes, as obras de arte depravadas são secretamente recusadas pelos contemplados juntamente com as bugigangas a que são assimiladas pelos meios de comunicação" (p.150). Desse modo, contraditória e ideologicamente, a elevação cultural das massas, condição indispensável à diferenciação em relação à integração total pela indústria capitalista assim como à passagem da condição de heteronomia à de autonomia, ao tempo em que é apresentada como slogan burguês que busca justificar a suposta democratização, em verdade reforça o seu contrário, ou seja, a permanência do estado de embrutecimento das massas e, por consequência, da barbárie social.

A "purificação da palavra" constitui outra consequência da indústria cultural. A unidirecionalidade sob a qual são produzidos os seus bens faz com que o espectador desenvolva uma consciência passiva que, no âmbito da conduta humana, expressa-se como impotência diante da possibilidade de transformar aquilo que lhe é apresentado. Essa unidimensionalidade caracteriza-se pela informação repassada claramente ao receptor dos bens, não lhe deixando qualquer possibilidade de reflexão sobre as contradições dos produtos apresentados. Segundo Horkheimer e Adorno (1985, p. 153), "quanto mais completamente a linguagem se absorve na comunicação, quanto mais as palavras se convertem de veículos substanciais do significado em signos destituídos de qualidade, quanto maior a pureza e a transparência com que transmitem o que se quer dizer, mais impenetráveis elas se tornam". Apresentando-se como deuses sobrenaturais intocáveis e impenetráveis, tais produtos são, cada vez mais, aceitos e assimilados pelos espectadores, implicando um círculo vicioso aparentemente de difícil rompimento.

A velocidade com que os meios de comunicação veiculam os bens da indústria cultural implica também o esvaziamento do conceito, processo pelo qual a palavra anunciada não invoca diretamente a experiência real à qual ela se refere, mas, sim, é absorvida como se não apresentasse intrínseca relação com a realidade, ou melhor, como se não emanasse do mundo de carne e osso dos homens.

Ao invés de trazer o objeto à experiência, a palavra purificada serve para exibi-lo como instância de um aspecto abstrato, e tudo o mais, desligado da expressão (que não existe mais) pela busca compulsiva de uma impiedosa clareza, se atrofia também na realidade. $O$ ponta-esquerda no futebol, o 
camisa-negra, o membro da Juventude Hitlerista etc. nada mais são do que o nome que os designa. (Horkheimer e Adorno, 1985, p. 154)

Apresentados dessa maneira, tais produtos omitem as contradições inerentes à sociedade capitalista contemporânea. A partir daí, talvez pudéssemos compreender o quanto a indústria cultural colabora para a anulação de qualquer força de mobilização em massa contra as atrocidades produzidas por essa sociedade, tais como a desigualdade social, os preconceitos, os fanatismos, etc., pois "o tipo de experiência que personalizava as palavras ligando-as às pessoas que as pronunciavam foi esvaziado, e a pronta apropriação das palavras faz com que a linguagem assuma aquela frieza que era própria dela apenas nos cartazes e na parte de anúncios dos jornais" (Horkheimer; Adorno, 1985, p. 155). Da consequente frieza advinda da absorção da cultura pela indústria, mantêm-se a frieza que permeia as relações interpessoais e o degradável isolamento individual num mundo em que os homens encontram-se cada vez mais próximos.

\section{O COMPUTADOR E SUA AMBIVALÊNCIA}

Certamente, a submissão da cultura aos interesses capitalistas não se deu por decreto, mas, antes, coincide com a intensificação do desenvolvimento das ciências e das tecnologias, sobretudo no contexto das grandes guerras mundiais na primeira metade do século XX. A garantia de êxito bélico entrava numa etapa até então inexistente: a nação que apresentasse melhores equipamentos tecnológicos conquistaria vitórias sem numerosas baixas de soldados, pois, à medida que uma arma conseguisse atingir alvos a uma distância até então impensável, ela poderia substituir as pessoas em combate. Uma das grandes invenções que resultou de exigências bélicas foi o computador. Segundo Rougemont (1983, p. 25) "o primeiro computador, o ENIAC, construído e terminado em 1945 na Universidade de Pensilvânia, havia sido encomendado pelo laboratório de balística do exército americano". Fato esse já a nos indicar que essa técnica não nasceu visando à sabedoria nem para satisfazer uma necessidade especificamente humana, mas, antes, nasceu para atender a necessidades específicas da guerra.

Como muitas outras produções humanas, o surgimento e o desenvolvimento das novas tecnologias foram e são apresentados como avanços significativos, como descobertas que levariam a humanidade a uma nova etapa de bem estar social, por meio de seus benefícios, que vão, na atualidade, da erradicação de problemas de saúde ao conhecimento de outros planetas. $A$ confiança foi tamanha que a ciência e a tecnologia acabaram transformando- 
se em deusas na sociedade industrial ${ }^{4}$. No entanto, conforme nos esclarece Rougemont, as vantagens anunciadas não condizem com as condições de existência da sociedade atual, as quais indicam, sim, uma ambivalência das novas tecnologias, pois, segundo ele,

não nos esqueçamos jamais da ambivalência inevitável de todas as nossas tecnologias. A revolução técnica e a automatização deviam conduzir à era do lazer, e estamos na era do desemprego. A produtividade da indústria anunciava a abundância. E temos penúria crescente no Ocidente e fome no Terceiro Mundo. A informática nos propõe hoje pensar por nós mesmos, mais rápido que nós; ela porém cria o risco de atrofiar nossas faculdades de memória, de julgamento e de criação, multiplicando uma espécie próspera em débeis mentais eficazes. (Rougemont, 1983, p. 25)

Com base nesse autor, é possível inferir que a sociedade informatizada, que nos é apresentada como altamente vantajosa, sobretudo pela facilidade de acesso à informação de qualquer espécie, para o que basta apertar um botão, não torna mais humana a vida das pessoas, mas, antes, desumana ou estúpida. A atrofia da faculdade de discernimento crítico imputada pelos bens produzidos pela indústria cultural encontra eco no ascendente processo de informatização na sociedade atual. Ainda assim, os resultados obtidos por meio do desenvolvimento da informática são anunciados unicamente como positivos. Algumas dessas vantagens são, por exemplo, a rapidez no processamento de dados e as facilidades na resolução de funções e cálculos demasiado complexos. No entanto, vejamos a ambivalência dessas vantagens.

São inegáveis as vantagens trazidas pelo computador no tocante à rapidez nas análises lógicas, no processamento de dados e nos cálculos. Pois, segundo Rougemount, a redução, de doze meses para uma semana, dos cálculos para a construção de uma barragem, as vantagens nos serviços hospitalares, os recenseamentos que não mais utilizam papel, as estatísticas, o cálculo de impostos, ou mesmo a utilização para as defesas das nações, constituem alguns exemplos da utilidade do computador. No entanto, o argumento favorável à rapidez trazida pela informática esbarra em alguns limites, pois, se no domínio dos cálculos e das operações lógicas, a rapidez implica menor custo além de maior eficiência na produção, o mesmo não se pode dizer quando se trata de outros domínios humanos, tais como o biológico, o afetivo, o artístico, o pedagógico, o ético, o espiritual. Nesses domínios, a duração - e não a rapidez - desempenha papel fundamental na experimentação da vida humana, como é, por exemplo, o caso da música. 
Dizem-nos que o computador, interrogado sobre um problema psicológico, "pensa" muito mais rápido que o cérebro humano. Isto porém não é útil para a pessoa que interroga, porque ser-lhe-á necessário o mesmo tempo para compreender realmente a resposta de que ela não se serviu para encontrar, isto é, para viver o processo de mudança que permite realizá-la. (RougEMONT, 1983, p. 30)

Portanto, o problema não é a rapidez decorrente da informática, mas sim a generalização das vantagens do âmbito objetivo para o âmbito subjetivo. A experimentação e a vivência, as quais demandam prazo, são necessárias à assimilação adequada de alguns conceitos, contextos e situações. Ou, ainda, em todos os domínios que envolvem a subjetividade, a psicologia ou a afetividade da pessoa humana, "a rapidez indefinidamente multiplicada torna-se fator destrutivo de tudo aquilo que requer um trabalho de assimilação, de digestão, de integração ou de apropriação. Seria estúpido alimentar o corpo e o espírito mais rápido e com mais frequência do que eles possam digerir e assimilar" (p. 30). Desse modo, talvez não fosse inapropriado se as pessoas defendessem, em vez da rapidez indiscriminada, uma desejável lentidão nas relações e domínios humanos, visando experienciar os fatos cotidianos de modo intenso e significativo, com consciência de seus sentidos e significados.

Articulada à rapidez, outra vantagem anunciada pelos defensores do uso indiscriminado das novas tecnologias é relacionada ao auxílio à educação, isto é, em relação às facilidades que o computador pode fornecer às gerações que a ele têm acesso na resolução de problemas complexos ao ser humano. Chega-se, em alguns extremos, a imaginar a substituição de professores por computadores no processo educacional. Importante é destacar que, como a rapidez em efetuar cálculos lógicos apresenta vantagens, as facilidades podem ser perfeitamente utilizadas para o planejamento e a programação de tarefas de algumas profissões, como a engenharia ou mesmo a medicina. No entanto, as facilidades que decorrem da informática constituem, por outro lado, problemas no âmbito da orientação pedagógica. De acordo com Rougemont (1983, p. 32), um desses problemas é que"se se oferecem facilidades aos jovens menores de 18 anos (as sinapses se desenvolvem até esta idade) tornamos-Ihes o cérebro preguiçoso, que se atrofia como as pernas daquelas [pessoas] que não andam quinhentos metros a pé, mas que pegam o seu carro ou a sua moto". A exemplo do que ocorre com o uso da calculadora pelos jovens estudantes para realizar um cálculo que não se aprende mais a fazer nem mesmo para assimilar as mais simples operações matemáticas, o computador tende a substituir a inteligência e o saber de quem o usa desavisadamente, porque se propõe pensar e assimilar no lugar do seu usuário. 
Identificadas as ambivalências das novas tecnologias e, dentre elas, a que se tem disseminado em escala planetária na virada do século XX para o século XXI, o computador, Rougemont formula a seguinte questão: precisarse-ia então destruir ou parar a técnica ou, no caso em questão, a informática? Segundo ele, esta não é a melhor saída, pois não se pode desinventar nada. O desafio posto não está em recuar na história e tomar outros caminhos para a humanidade, algo possível apenas nas ilusões produzidas pela indústria cultural, mas, a partir do contexto atual, repensar os usos que têm sido feitos das tecnologias, redirecionando-os para atender a necessidades da "pessoa humana".

A técnica em si é neutra, instrumento a serviço do homem, de todo homem, do que há de bom e de mau nele. Mas,com efeito, o mau tem um pouco mais de ocasiões de aproveitar esta neutralidade do que o bom. Porque a técnica tem por função facilitar nosso esforço e multiplicar-lhe os efeitos. Ora, o mal é em geral mais fácil de ser feito do que o bem. Passado um certo limite quantitativo, certos efeitos do mal podem se tornar irreversíveis, portanto, mortais. (Rougemont, 1983, p. 34)

No momento atual, o fato de que um sem-número de pessoas faz uso da informática e do computador de forma indiscriminada é motivo para todos nós, educadores das gerações contemporâneas e futuras, compreendermos esse fenômeno e procurarmos, pelo menos, alertar sobre os perigos desse uso irresponsável. Pois é importante lembrar que, por mais que as novas tecnologias tenham apresentado a tendência de manter embrutecidas as pessoas, à educação cabe resistir a tal processo, zelando pelo esclarecimento das veladas contradições da sociedade contemporânea. Tarefa essa que, se para a maioria das pessoas parece irrealizável, constitui a gênese da educação moderna ocidental, que ainda se encontra em permanente construção.

\section{TELEVISÃO, CONSCIÊNCIA E COMPORTAMENTO HUMANOS}

Embora o computador e a internet, de modo mais significativo na atualidade, influenciem as gerações contemporâneas, a televisão, como meio de difusão dos produtos da indústria cultural que alcança a humanidade há mais tempo, também desempenha papel considerável na formação dos gostos, costumes, hábitos e atitudes, enfim, na formação do pensamento e do comportamento humanos. Aliás, em tempos da denominada "inclusão digital", pode parecer anacrônico discutir os efeitos e as consequências da televisão como meio de comunicação em massa, pois, por meio da rede mundial de computadores, interagem pessoas de todos os cantos do mundo. No 
entanto, além das contradições que recaem sobre a falaciosa inclusão digital, inicia-se, nesse princípio de século XXI, a era da televisão digital, que permite assistir a vídeos televisivos através, até mesmo, do celular. Portanto, pode até mudar a forma de acesso aos programas televisivos, mas, provavelmente, seus conteúdos permanecerão carregados de teor ideológico. Não será discutida aqui a gênese e o sentido da televisão, mas, antes, algumas questões relacionadas à forma de usá-la bem como sua dimensão ideológica na sociedade contemporânea, sobretudo como instrumento da indústria cultural.

A preocupação com o uso da televisão e com a ideologia propagada por ela não é recente. Em debate sobre a influência da televisão na formação de pessoas, promovido pela Rádio de Hesse em 1963, do qual participaram Theodor Adorno e Helmut Becker, já eram feitas algumas advertências sobre suas consequências para a formação das futuras gerações na Alemanha. Adorno, numa tentativa de desvelar aquilo que se encontra oculto nos programas televisivos, diz-nos que não é contra a televisão em si, mas adverte: "suspeito muito do uso que se faz em grande escala da televisão, na medida em que creio que em grande parte das formas em que se apresenta, ela seguramente contribui para divulgar ideologias e dirigir de maneira equivocada a consciência dos espectadores" (ADORNo, 1995, p. 77). Corolário dessa advertência é o reconhecimento de que, se fosse do interesse dos proprietários desse meio de produção de valores, idéias, pensamentos e comportamentos humanos não perpetuar as veladas contradições dessa sociedade, mas sim esclarecer o telespectador sobre elas, já poderíamos ter experimentado formas de vida alternativas à exploração, segregação e alienação a que são submetidos os homens desde os primórdios da sociedade industrial capitalista. Por isso, passado quase meio século do debate na Rádio de Hesse, parece-nos que o mau uso que se tem feito da televisão, tanto pelos produtores e programadores quanto pelos telespectadores como também o teor ideológico que envolve esse meio de comunicação em massa constituem pauta atualíssima de discussão.

Adorno (1995) considera a dimensão ideológica da televisão sob dois aspectos: o de geradora de falsa consciência e o seu caráter ideológico-formal. Quanto ao primeiro, a televisão é ideológica porque tenta incutir nas pessoas uma falsa consciência da realidade por meio da ocultação das contradições imanentes à sociedade industrial capitalista, além de procurar impor às pessoas um conjunto de valores como se fossem dogmaticamente positivos. "Por toda a parte onde a televisão aparentemente se aproxima das condições da vida moderna, porém ocultando os problemas mediante rearranjos e mudanças de acento, gera-se efetivamente uma falsa consciência" (p. 83). Quanto 
ao segundo aspecto, a televisão é ideológica por si mesma porque consegue desenvolver nos telespectadores uma espécie de vício televisivo, ou seja, por sua simples existência, ela converte-se no único conteúdo da consciência, desviando as pessoas, por meio da fartura de programas ofertados, daquilo que deveria constituir-se como prioridade na atenção e consciência humanas.

Merece destaque no debate entre Adorno e Becker a discussão sobre dois tipos de programas e sua absorção pelo telespectador: os programas de cunho político e as telenovelas. Embora não discutam o processo de construção de cada um deles, não é preciso ser especialista em televisão para perceber que são programados com intenções e interesses bastante diversos. Enquanto no primeiro predomina a dimensão racional sobre os fatos, seja no sentido de amainar seja no de explicitar as contradições sociais, no segundo predomina a dimensão emotiva. Enquanto um pode provocar a consciência da realidade, o outro é profundamente captado e armazenado pelo inconsciente, sendo esse, segundo Becker, o ponto de maior perigo, porque,

existe o perigo de os jovens procurarem imaginar o amor, por exemplo, tal como ele é apresentado na tevê, isto é, assumam para relações humanas muito diretas representações estereotipadas antes que eles mesmos as tenham vivido. E que em seu próprio desenvolvimento procedam fixados em representações estereotipadas. [Portanto] a questão relativa a como enfrentar esta situação coloca-se muito mais em relação a novelas de televisão do que em relação a programas acerca de assuntos políticos. (BECKER, In: AdoRno, 1995, p. 80-1)

O fato de a política geralmente ser apresentada com forte acentuação nos debates explicitando pontos de vista convergentes ou divergentes pode provocar no telespectador um senso crítico sobre a realidade, enquanto que no tocante às questões da vida cotidiana expressas nas novelas são veiculadas coisas que se transferem como muito mais força ao inconsciente. Na opinião de Adorno (1995, p. 81), "essas novelas são politicamente muito mais prejudiciais do que jamais foi qualquer programa político". Na sociedade contemporânea, percebe-se uma tendência à "facilitação da vida", isto é, aquilo que exige esforço tanto do físico como, sobretudo, do pensamento, é rapidamente colocado no rol de atividades desnecessárias, pois o entendimento é o de que se estamos numa era em que, para contatar uma pessoa do outro lado do mundo, basta apertar um botão do computador, por que usar o telefone ou, mesmo, dedicar-se ao tradicional trabalho de escrever uma carta? Talvez, por essa linha de raciocínio, pudéssemos compreender por que há grande desinteresse das gerações atuais em se envolver com programas de cunho político, os quais para serem acompanhados e compreendidos exigem aten- 
ção e rigor. No entanto, por outro lado, essas gerações apresentam vigorosa disposição para assistirem programas de diversão ou entretenimento.

Uma ilustração sobre como a televisão influencia na formação do pensamento e do comportamento das gerações contemporâneas, provocando uma (con)fusão entre a vida real e a vida no mundo das telinhas, pode ser obtida pelo relato de uma experiência da professora Rosa Maria Fischer com alunas de um curso de pedagogia. Nessa experiência, a intenção foi mostrar como a televisão habita a intimidade mais privada da vida das pessoas, ao ponto de expressar plenamente a inseparabilidade entre o público e a televisão. Dentro do tema geral sobre mídia e educação, em que um dos focos era a análise de programas televisivos, escolheram-se para discussão textos $\operatorname{críticos}^{5}$ elaborados sobre a apresentadora Xuxa. Segundo a professora, o objetivo consistia

não só em discutir com a turma sobre um dos mitos da televisão brasileira, fortemente ligado ao universo infantil, mas sobretudo mostrar as várias possibilidades de tratar um tópico da mídia, enfim, os pontos de vista distintos que uma crítica ou uma análise pode assumir. Também desejava assinalar, através do estudo dos textos, o quanto é importante recorrer a referenciais teóricos claros, quando nos propomos a fazer mesmo que uma breve análise dos produtos midiáticos, como, no caso, de uma das deusas do Olimpo televisivo brasileiro. (FISCHER, 2001, p. 22)

No entanto, à medida que as alunas faziam a leitura dos textos críticos, as reações eram surpreendentes, pois à grande maioria delas essa leitura causou um choque, sendo que apenas uma lembrou que, em se tratando de um estudo acadêmico, era necessário distanciar-se do objeto estudado. Da frustração experimentada pelas alunas resultaram depoimentos assaz emocionados, tais como:

"Não pode ser. Essa aí (dos textos) não é a Xuxa". Isso ali eles inventaram; a Xuxa nunca foi nem vai ser isso que eles dizem"; "Eu vejo a Xuxa até hoje, eu adoro a Xuxa, não pode ser assim"; "Professora, será que não dá pra entender, nós nascemos e já tinha a Xuxa na TV, a gente mamou vendo a Xuxa, se criou na frente da TV cantando e dançando com a Xuxa". (FISCHER, 2001, p. 23)

Fischer (2001) não esperava tamanha comoção na leitura daqueles breves textos e não compreendia como essas jovens, já cursando uma faculdade há pelo menos três semestres, até aquele momento em suas vidas não conseguiam distanciar-se criticamente em relação a uma personagem (real ou fictícia) de sua infância e adolescência. Depois das surpresas e dos choques, tanto da parte das alunas como da professora, suspeitou-se que, "como se 
tratava de algo que mobilizava fortes emoções, a capacidade de objetivar, de olhar'de fora', ficara momentaneamente suspensa", motivo pelo qual, antes de entrar numa discussão que exigia rigor e distanciamento na análise do objeto, foi preciso discutir com as alunas "o próprio sentido de aprender, de estudar, de dedicar-se a essa tarefa-sem-fim de surpreender-se com o não sabido, com o'jamais imaginado'”'(FISCHER, 2001, p. 24). Experiências como essas no âmbito, inclusive, do ensino superior revelam o quanto a distinção entre a vida real e a vida no mundo das telinhas parece cada vez mais diluir-se e esfumaçar-se. Como a indústria cultural produz periódica e sucessivamente ícones e ídolos para o telespectador, não se deve duvidar de que as surpresas, os choques, as emoções e as atitudes dessa experiência repitam-se permanentemente nas gerações contemporâneas por intermédio de outras personagens. Por isso, não nos parece abusivo dizer que tem predominado na sociedade contemporânea uma espécie de "infantilidade crônica", em relação à qual deve-se estar alerta e a ela resistir por meio do árduo trabalho de educar as futuras gerações, contrapondo-se a ela a necessidade de uma rigorosa formação cultural e crítica da ideologia da sociedade industrial.

A experiência acima nos permite, ainda, confirmar que as preocupações de Adorno e Becker sobre os possíveis efeitos nefastos da televisão atualizam-se a cada dia. Assim, segundo eles, algumas questões deveriam orientar as pessoas sobre a dimensão ideológica da televisão e sobre o uso indiscriminado que fazem dela, tais como:

1) Como ver tevê sem ser iludido, ou seja, sem se subordinar à televisão como ideologia?

$2^{\circ}$ ) Como podemos conseguir que o efeito de esclarecimento da televisão se amplie e os perigos que ela representa se reduzam a um mínimo inevitável?

3०) Ou ainda, como fazer para que a televisão represente um avanço e não um retrocesso ao conceito de formação cultural?

(AdoRno, 1995, pp. 78, 79 e 95).

Possivelmente, as respostas a essas fundamentais e complexas questões, que poderiam indicar outro sentido para o fenômeno televisivo, devam passar pelo entendimento do quanto se modificaram o pensamento e o comportamento das gerações atuais, que sofrem diuturnamente a influência da televisão. Para compreender a relação entre televisão e comportamento humano, talvez devêssemos questionar-nos sobre o que significa para essa geração estar informada ou buscar informações? Como se formam seus gostos estéticos? O que seus olhos vêem na televisão? O que lhes dá prazer nas imagens e sons veiculados pela televisão? Com quais personagens ou 
situações essa geração se identifica? Como representam os sentimentos e que relações sociais são aprendidas a partir da televisão? Perguntas como essas reforçam a complexidade de compreender-se a relação entre a televisão e as gerações atuais e, dentro dessa complexidade, é preciso reconhecer a necessidade de procurar-se desvelar o teor ideológico dos programas televisivos, mesmo que, no atual momento, as ideologias tenham alcançado mais pessoas do que o seu contrário, ou seja, o esclarecimento.

THE CULTURAL INDUSTRY, COMPUTER AND TELEVISION: CONSEQUENCES FOR HUMAN AWARENESS AND BEHAVIOR IN CONTEMPORARY SOCIETY

ABSTRACT: This article is divided in three. In the first part, broader aspects of the relation between the cultural industry are discussed as well as certain implications for human awareness and behavior. In the second part, one of the main technologies is dealt with, that which is being used with each passing day by a greater number of people - the computer. The last part discusses the ideological dimensions of television and the false awareness which results from the illusions it inculcates. The implications of these technologies for the changes in the thinking and behavior of the present generation will be analyzed. The analyses will be principally based on those of Max Horkheimer and Theodor W. Adorno on the cultural industry and television and also those of Denis de Rougemont on the advantages being heralded by the new technologies.

KEYWORDS: Cultural industry. Technology. Human behavior. Contemporary society.

\section{NOTAS}

1. Como os mal informados, simpatizantes ou defensores da denominada ideologia pós-moderna.

2. Para alguns, como Fukuyama, teríamos chegado ao fim da história (ANDERSON, 1992). Os argumentos utilizados para a deflagração do fim da história surgem num contexto em que o pós-moderno projeta-se no âmbito político e filosófico. Comuns nessas perspectivas são, primeiro, a resignação frente ao modo de produção capitalista, o qual se teria consolidado como a única forma de organização social possível, e, segundo, o caráter anti-histórico na análise e compreensão das atitudes humanas frente aos fenômenos sociais. No entanto, segundo Hobsbawm (1995, p. 18), alguns "ensaístas filosóficos que detectaram o'fim da história' na queda do império soviético estavam errados. $O$ argumento é melhor quando se afirma que o terceiro quartel do século assinalou o fim dos sete ou oito milênios de história humana iniciados com a revolução da agricultura na Idade da Pedra".

3. A expressão Indústria Cultural foi criada por Horkheimer e Adorno em 1944, num estudo em que se revela a absorção da cultura pela indústria e a subordinação da 
cultura aos interesses da economia capitalista, processos que influenciam as relações de produção por meio do investimento na alienação subjetiva através dos meios de comunicação, ao alimentar um mundo ilusório para os sujeitos que, por sua vez, mantêm-se presos às relações de dominação social e política (cf. HORKHEIMER e AdoRNo, 1985, p. 113-156).

4. Conforme Horkheimer (2002), assim como a razão teria a finalidade de livrar os homens da situação de heteronomia e menoridade na qual se encontravam, a ciência teria como finalidade a investigação dos fatos da realidade, por meio da objetividade inerente ao método científico. No entanto, o desenvolvimento das forças produtivas na sociedade industrial capitalista e, consequentemente, o aperfeiçoamento do aparato tecnológico implicaram a submissão da ciência ao processo de instrumentalização e burocratização. De fins a meios, eis a mudança epistemológica na sociedade da administração total. Ou seja, da finalidade de livrar a humanidade de um período de trevas e mistificações por meio da análise objetiva da realidade, passou à condição de meio para o desenvolvimento das forças produtivas sob a égide dos interesses da indústria capitalista, levando ao predomínio da dominação, da exploração e da heteronomia. Por esse motivo, apoiando-se no materialismo histórico-dialético, Horkheimer conclui que vivemos um novo período de trevas, no qual tem predominado a dimensão instrumentalizada da ciência, em detrimento de sua dimensão esclarecedora da realidade.

5. Os textos trabalhados pela autora foram: 10) "Eu acredito na tristeza da Xuxa”, de Eugênio Bucci, publicado no livro Brasil em tempo de TV, São Paulo: Boitempo, 1999, p. $150-151 ; 2^{\circ}$ ) "Xuxa, a deusa da infertilidade", de Jefferson Barros, publicado no livro Caleidoscópio eletrônico, Rio de Janeiro: Timbre, 1989, p. 17-19; e 3) "Xuxa de Neve e seus baixinhos", de Muniz Sodré, publicado em O Brasil simulado e o real. Rio de Janeiro: Fundo, 1991, p. 41-43.

\section{REFERÊNCIAS}

ADORNO, T. W. Televisão e formação. In: . Educação e emancipação. Rio de Janeiro: Paz e Terra, 1995.

ANDERSON, P. O fim da história: de Hegel a Fukuyama. Rio de Janeiro: Jorge Zahar Ed., 1992.

FiSCHER, R. M. B. Televisão e educação: fruir e pensar a TV. Belo Horizonte: Autêntica, 2001.

HOBSBAWM, E. J. Era dos extremos: o breve século XX. 2. ed. São Paulo: Companhia das Letras, 1995.

HORKHEIMER, M.; ADORNO, T. W. A indústria cultural: o esclarecimento como mistificação das massas. In: Dialética do esclarecimento: fragmentos filosóficos. Rio de Janeiro: Jorge Zahar Ed., 1985.

HORKHEIMER, M. Eclipse da razão. São Paulo: Centauro, 2002. 
MARX, K. Miséria da filosofia. São Paulo: Ícone, 2004.

ROUGEMONT, D. Informação não é saber. Revista Internacional de ciências humanas, Brasília, n. 4, 1983, p. 23-35.

Luís CÉSAR SOUZA é professor no curso de Licenciatura em Educação Física da UFG/CAJ, atuando principalmente nas áreas de Educação, Fundamentos da Educação e Fundamentos da Educação Física. Mestre em Educação. Especialista em Educação Física Escolar.

URL http://lattes.cnpq.br/1480252698796928; e-mail: lucceso@ yahoo.com.br 